\title{
Removal of heavy metals using a brewer's yeast strain of Saccharomyces cerevisiae: Chemical speciation as a tool in the prediction and improving of treatment efficiency of real electroplating effluents
}

\author{
Manuela D. Machado ${ }^{\mathrm{a}, \mathrm{b}}$, Eduardo V. Soares ${ }^{\mathrm{a}, \mathrm{c}, * *}$, Helena M.V.M. Soares ${ }^{\mathrm{b}, *}$ \\ a Bioengineering Laboratory, Chemical Engineering Department, Superior Institute of Engineering from Porto Polytechnic Institute, \\ Rua Dr António Bernardino de Almeida, 431, 4200-072 Porto, Portugal \\ ${ }^{\mathrm{b}}$ REQUIMTE-Department of Chemical Engineering, Faculty of Engineering of Porto University, Rua Dr Roberto Frias, $s / n, 4200-465$ Porto, Portugal \\ ' IBB-Institute for Biotechnology and Bioengineering, Centre for Biological Engineering, Universidade do Minho, Campus de Gualtar 4710-057, Braga, Portugal
}

\section{A R T I C L E I N F O}

\section{Article history:}

Received 10 September 2009

Received in revised form 26 February 2010

Accepted 10 April 2010

Available online 24 April 2010

\section{Keywords:}

Bioremediation

Biosorption

Chemical speciation

Heavy metals

Metals bioavailability

\begin{abstract}
A B S T R A C T
In the present work, the influence of the competitive effect of inorganic ligands (carbonates, chlorides, fluorides, phosphates, nitrates and sulphates), which can be present in real multi-metal electroplating effluents, on the biosorption of chromium, copper, nickel and zinc ions by yeast cells of Saccharomyces cerevisiae was rationally examined. Additionally, chemical speciation studies allowed optimizing the amount of yeast biomass to be used in the treatment of effluents contaminated with nickel.

The applicability of chemical simulation studies was tested using two simulated effluents and validated using one real electroplating effluent, all containing high concentrations of nickel (about $303 \mu \mathrm{mol} \mathrm{l}^{-1}$ ). For nickel removal, heat-killed biomass of a brewing flocculent strain of $S$. cerevisiae was used, in a batch mode. After the implementation of the bioremediation process ( $12 \mathrm{~g}$ dry weight $\mathrm{l}^{-1}$ of yeast cells), the concentration of nickel in the real effluent $\left(34 \mu \mathrm{moll}^{-1}\right)$ reached the quality criteria for industrial effluents discharge, after the second or third batch according to the U.S.-Environmental Protection Agency and Portuguese law, respectively. This corresponded to a removal of nickel of $89 \%$.
\end{abstract}

(C) 2010 Elsevier B.V. All rights reserved.

\section{Introduction}

The threat of heavy metal pollution to public health and wildlife lead to an enlarged interest in the development of effective technologies for heavy metals immobilization in a non-bioavailable form or their re-speciation into less toxic forms. The current technologies (precipitation, ion exchange, reverse osmosis or evaporation) have been shown inadequate or expensive; conversely, the use of a biological-based technology seems to be a very attractive way of metal ions removal [1].

Flocculent yeast cells of Saccharomyces cerevisiae constitute a new approach in the heavy metals bioremediation [2]. Recently, it was shown that brewing cells of $S$. cerevisiae, heat-killed at $45^{\circ} \mathrm{C}$, retain their flocculation ability in wastewaters with different heavy metals composition [3] and present a greater metals

\footnotetext{
* Corresponding author. Tel.: +35122 5081650; fax: +351225081449.

** Corresponding author at: Bioengineering Laboratory, Chemical Engineering Department, Superior Institute of Engineering from Porto Polytechnic Institute, Rua Dr António Bernardino de Almeida, 431, 4200-072 Porto, Portugal. Tel.: +35122 8340500; fax: +351228321159.

E-mail addresses: evs@isep.ipp.pt (E.V. Soares), hsoares@fe.up.pt (H.M.V.M. Soares).
}

uptake capacities than live cells [4], being very promissory for use in the treatment of heavy metals-loaded effluents. Due to the autoaggregation properties of this biomass, the solid-liquid separation process after effluent treatment is strongly facilitated, overcoming the need of cell immobilization (like gel entrapment) which, on large engineering scale, can be prohibitively expensive. Flocculent cells can be used in stirred tank reactors, operating in a batch or continuous mode without need of energy input for solid/liquid (biomass/effluent treated) separation stage (like it is required in centrifugation, filtration or flotation), prior to subsequent regeneration/metal recovery or disposal stage [2,3]. Moreover, the natural aggregation properties of flocculent yeast cells allows the use, in a batch mode, of the sedimentation tanks already available in the wastewater treatment plants of the electroplating industries without the need of any further capital investment.

Yeast metal accumulation is affected by several factors such as $\mathrm{pH}$, redox potential $\left(E_{\mathrm{h}}\right)$, presence of anions, cations and soluble organic compounds. Some of these factors can act at different levels simultaneously. For instance, $\mathrm{pH}$ of the solution affect the percentage of ionized groups of yeast cell wall; at low $\mathrm{pH}$, the increase of protonation of yeast cell wall ligands decrease metals adsorption [5-11]. Simultaneously, $\mathrm{pH}$ affect metal speciation (the different physicochemical forms of the metal in solution, which together make up its total concentration) [12] and consequently the avail- 
able metal (i.e., the free and labile metal) to be sequestered by the microorganisms. On the other hand, the increase of $\mathrm{pH}$ can result in the precipitation of metals hydroxides, reducing metal accumulation by the biomass [13]. The presence of anions (carbonates, chlorides, fluorides, phosphates and sulphates) in solution can complex metal ions and thus reduce or inhibit their adsorption to $S$. cerevisiae [14-16]. Heavy metals can also be complexed by organic compounds (ligands present in the effluents or/and cellular compounds); these soluble ligands can compete with the cells for the metals, reducing the efficiency of heavy metals removal [17-19]. Redox potential can also affect the speciation of a given element; for example, chromium exists as $\mathrm{Cr}(\mathrm{VI})$ or $\mathrm{Cr}(\mathrm{III})$ according to the $E_{\mathrm{h}}$ of the solution. The presence in solution of other cations besides the metals of interest can reduce heavy metals accumulation by biomass, by competition for binding sites on yeast cell wall $[6,20]$.

In recent years, the importance of chemical speciation in the treatment of wastewaters contaminated with heavy metals has been emphasized [21-23]. Romera et al. [24] compared the biosorption of different metal ions $(\mathrm{Cd}, \mathrm{Cu}, \mathrm{Ni}, \mathrm{Pb}$ and $\mathrm{Zn})$ by the marine brown alga Fucus spiralis; the predicted (theoretical) sorption values calculated using the speciation program PHREEQCI, were compared with experimental values. The influence of inorganic species distribution of $\mathrm{Hg}(\mathrm{II}), \mathrm{Pt}$ and $\mathrm{Pd}$, as a function of the $\mathrm{pH}$ of the solution and of chloride concentration, on the sorption capacity by the macroalga Cystoseira baccata [25] and by sulfate-reducing bacteria [26] was also examined. However, all these works were carried out in simple water synthetic solutions. Real effluents are more complex matrices because they usually have multi-elements and inorganic ligands in competition; these aspects are particularly critical when nickel is one of the metal ions to be removed due to the low affinity of nickel to biomass [4,27].

In this work, the influence of the matrix of real effluents on the removal of heavy metals by bioremediation with heat-killed biomass of $S$. cerevisiae was evaluated by analysing metals chemical speciation and validated for nickel through the bioremediation of a real electroplating effluent and two synthetic effluents. This work also explores the importance of metal chemical speciation in order to predict and optimize the treatment of real effluents, where multi-metal and multi-ligands can be present.

\section{Materials and methods}

\subsection{Strain, media and culture conditions}

In this work, the flocculent brewing strain of $S$. cerevisiae National Collection of Yeast Culture (NCYC) 1364 was used. The strain was routinely maintained at $4{ }^{\circ} \mathrm{C}$, on YEPD agar

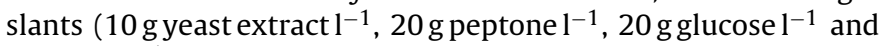
20 g agar $^{-1}$ ).

Pre-cultures were prepared in $40 \mathrm{ml}$ of YEPD broth $\left(3\right.$ gyeast extract $^{-1}, \quad 5$ g peptone $^{-1}$ and 20 g glucose $^{-1}$ ) in $100 \mathrm{ml}$ Erlenmeyer flasks. Cells were incubated at $25^{\circ} \mathrm{C}$ on an orbital shaker Sanyo Gallenkamp IOC 400 (West Sussex, UK), at $150 \mathrm{rpm}$, during $24 \mathrm{~h}$.

Cultures in YEPD broth with 50 g glucose $\mathrm{l}^{-1}$ were prepared by inoculating 11 of culture medium in 21 Erlenmeyer flasks with $4 \%$ $(\mathrm{v} / \mathrm{v})$ from pre-cultures. Cells were incubated in the same conditions of the pre-culture for $48 \mathrm{~h}$.

\subsection{Preparation of cell suspensions}

After growth, cells were harvested by centrifugation $(2000 \mathrm{~g}$, $5 \mathrm{~min}$ ) and washed two times with $30 \mathrm{mmoll}^{-1}$ ethylenediaminetetraacetic acid (EDTA) solution (Merck) and two times with deionized water. Cells were heat-inactivated by drying live biomass, at $45^{\circ} \mathrm{C}$, until constant weight. In a previous work, it was found that with this treatment all the biomass is dead [4]. After being heat-killed, cells were washed five times with an excess of deionized water.

\subsection{Determination of biomass}

Cells concentration was determined spectrophotometrically (Unicam, Helios $\gamma$ ) at $600 \mathrm{~nm}$ after appropriate dilution of the samples in EDTA solution ( $30 \mathrm{mmoll}^{-1}$ ) to prevent cell aggregation. Calibration curves (absorbance versus either number of cells or dry weight) were previously made.

\subsection{Industrial effluent characterization}

In this study, an effluent from an electroplating industry from the Metropolitan Area of Oporto, Portugal, was used. To characterize this effluent, $\mathrm{pH}$ value, redox potential, total heavy metals $(\mathrm{Cu}, \mathrm{Ni}, \mathrm{Zn}$ and $\mathrm{Cr}$ ), total inorganic ligands (chlorides, fluorides, phosphates, nitrates and sulphates) and total organic and inorganic carbon concentrations were determined. Inorganic ligands were analysed according to Standard Methods [28]. All determinations were done at least in duplicate. Thus, fluorides were determined by direct potentiometry using a fluoride-ionselective electrode (ISE) (Orion 96-09, Boston, USA), assembled to a Kent $7045 \mathrm{pH}$ meter. Chlorides were determined by the argentometric method. Nitrates were determined by direct potentiometry using a nitrate-ion-selective electrode (ISE) (Crison, Barcelona, Spain) assembled to a Crison MicropH 2002 pH meter. Sulphates were determined by a turbidimetric method. Concentration of inorganic phosphate was determined by the molybdate method.

Total carbon (TC) and inorganic carbon (IC) was determined using the analyser TOC-5000A (Shimadzu). Total organic carbon (TOC) was calculated by the difference of TC and IC.

Total heavy metals concentration was determined by Atomic Absorption Spectroscopy (AAS) with flame atomization in a Perkin Elmer AAnalyst 400 spectrometer (Norwalk, CT, USA). $\mathrm{Cr}(\mathrm{VI})$ was determined by a colorimetric method (with diphenylcarbazide). The difference between total and hexavalent chromium was taken as trivalent chromium concentration.

\subsection{Preparation of the synthetic effluents}

Two synthetic effluents (named, synthetic 1 and synthetic 2), with the same amount of heavy metals present in industrial effluent, prepared from metal salt stock solutions of $\mathrm{Cu}\left(\mathrm{NO}_{3}\right)_{2}, \mathrm{NiCl}_{2}$, $\mathrm{ZnCl}_{2}$ and $\mathrm{Cr}\left(\mathrm{NO}_{3}\right)_{3}$, were produced in $\operatorname{MES} \mathrm{pH}$ buffer $\left(10 \mathrm{mmol}^{-1}\right)$, at $\mathrm{pH}$ 6.0. In the case of synthetic effluent 1 , the same amount of inorganic ligands $\left(\mathrm{Cl}^{-}, \mathrm{NO}_{3}{ }^{-}\right.$and $\left.\mathrm{SO}_{4}{ }^{2-}\right)$ of the industrial effluent was also added. MES is a suitable pH buffer for heavy metal studies because it does not complex with several metal ions, such as cadmium, copper, lead, and zinc $[29,30]$.

\subsection{Computer chemical simulations}

Chemical speciation calculations were carried out using the MINEQL+ software (version 4.5) [31]. For each case, total heavy metals and ligands (inorganic ligands quantified in the real effluent and inactivated biomass) concentrations, as well as all the affinity constants between heavy metals and ligands [4,6,32] and solubility product constants [32] were introduced in the MINEQL+. 


\subsection{Bioremediation of effluents using inactivated biomass in a batch reaction system}

The efficiency of using inactivated yeast biomass in the removal of heavy metals from electroplating effluents was tested using three effluents: one real and two synthetics.

Industrial effluent was adjusted to $\mathrm{pH} 6.0$ with $\mathrm{NaOH}$. Then, the effluent was allowed to stand undisturbed for one night and was filtered through a $0.45 \mu \mathrm{m}$ pore size membrane.

Washed cells, with a concentration near $12 \mathrm{~g}$ dry weight $\mathrm{l}^{-1}$, were added to the effluents and shaken in $500 \mathrm{ml}$ plastic flasks, at $150 \mathrm{rpm}$, at $25^{\circ} \mathrm{C}$. After $30 \mathrm{~min}$ of contact between the biomass and the effluent, cells were removed and the supernatant added to new yeast biomass, in a subsequent batch. Kinetic studies performed in a previous work [4] have shown that a contact time of 30 min was enough to reach the equilibrium between dead cells and metals in solution.

Control experiments were done incubating the effluents in the absence of biomass, in the same conditions described above; these control experiments showed that no appreciable amount of nickel (less than 1\%) was adsorbed to the plastic flasks. Heavy metals remained in solution were determined as described above.

\subsection{Reproducibility of the results}

All experiments were performed in duplicate and repeated, at least, three times $(n=6)$.

\section{Results and discussion}

\subsection{Physicochemical characterization of industrial effluent}

The real effluent was collected from a Portuguese electroplating industry, which is devoted to the production of bath accessories. First, physicochemical characterization of the effluent was performed. For this purpose, total concentrations of metals, inorganic ligands, total carbon and total organic carbon were determined (Table 1); the permissible discharge levels for various heavy metals and inorganic ligands regulated by the Portuguese law [33] were included. European Union (EU) has some directives concerning the discharge of dangerous chemicals, which should be followed by the countries. However, all these documents are general guidelines without any limit discharge criteria. Thus, each country of the EU has its own laws, which take into account the communitarian directives. For comparative purposes and in order to give a wider regulatory perspective, the U.S.-Environmental Protection Agency [34] criteria were also included.

The analysis of Table 1 evidences that nickel concentrations is above US-EPA and Portuguese limit discharge of effluents and thus should be removed before the effluent will be discharged. The presence of metals in the effluent is mainly due to periodical discharge of rinsing waters of electrolytic lines. The values of redox potential $(238 \mathrm{mV})$ and $\mathrm{pH}(2.0)$ indicate that chromium should be present as chromium (III) [35], which is in the agreement with the obtained results (Table 1 ). Thus, the concentration of all other metals besides nickel (chromium, copper and zinc), as well as inorganic ligands, are below the legal limit of discharge.

Additionally, Table 1 also point outs that molar concentrations of chlorides and sulphates $\left(2.55 \mathrm{mmol}^{-1}\right.$ and $3.89 \mathrm{mmoll}^{-1}$, respectively), even if below the legal limits, are about 10 times higher than those of nickel concentration $\left(0.303 \mathrm{mmoll}^{-1}\right)$. The presence of these ligands in the electroplating effluents comes from the pickling and rinsing waters and, in some industries, from the addition, in the treatment tank, of an acid (chloridric acid) solution of bissulphite, which is used for reduction of chromium (VI) to chromium
Table 1

Physicochemical characterization of a raw industrial effluent from an electroplating unit. The level of contaminants are compared to the U.S.-Environmental Protection Agency (US-EPA) [34] and the Portuguese [33] wastewater limit discharge criteria.

\begin{tabular}{|c|c|c|c|}
\hline & \multicolumn{2}{|c|}{ Wastewater limit discharge criteria } & \multirow[t]{2}{*}{ Industrial effluent } \\
\hline & US-EPA & Portuguese law & \\
\hline $\mathrm{pH}$ (units) & & $6.0-9.0$ & 2.0 \\
\hline$E_{\mathrm{h}}(\mathrm{mV})$ & & & 238 \\
\hline $\mathrm{TC}\left(\mathrm{mg} \mathrm{l}^{-1}\right)$ & & & 11.5 \\
\hline $\mathrm{TOC}\left(\mathrm{mg} \mathrm{l}^{-1}\right)$ & & & 10.7 \\
\hline $\mathrm{IC}\left(\mathrm{mg} \mathrm{l}^{-1}\right)$ & & & 0.8 \\
\hline $\mathrm{Cl}^{-}\left(\mathrm{mg} \mathrm{l}^{-1}\right)$ & & & 90.5 \\
\hline $\mathrm{F}^{-}\left(\mathrm{mgl}^{-1}\right)$ & & & 12 \\
\hline $\mathrm{NO}_{3}^{-}\left(\mathrm{mg} \mathrm{l}^{-1}\right)$ & & 50 & 7.8 \\
\hline $\mathrm{SO}_{4}{ }^{2-}\left(\mathrm{mg} \mathrm{l}^{-1}\right)$ & & 2000 & 374 \\
\hline $\mathrm{PO}_{4}{ }^{3-}\left(\mathrm{mg} \mathrm{l}^{-1}\right)$ & & & 0.08 \\
\hline \multicolumn{4}{|l|}{$\mathrm{Cu}^{2+}$} \\
\hline$\left(\mathrm{mg} \mathrm{l}^{-1}\right)$ & 3.38 & 1.0 & 0.5 \\
\hline$\left(\mu \mathrm{moll}^{-1}\right)$ & 53.1 & 16 & 8 \\
\hline \multicolumn{4}{|l|}{$\mathrm{Ni}^{2+}$} \\
\hline$\left(\mathrm{mg} \mathrm{l}^{-1}\right)$ & 3.98 & 2.0 & 17.8 \\
\hline$\left(\mu \mathrm{moll}^{-1}\right)$ & 67.8 & 34 & 303 \\
\hline \multicolumn{4}{|l|}{$\mathrm{Zn}^{2+}$} \\
\hline$\left(\mathrm{mg} \mathrm{l}^{-1}\right)$ & 2.61 & NS & 0.8 \\
\hline$\left(\mu \mathrm{moll} \mathrm{l}^{-1}\right)$ & 39.9 & NS & 12 \\
\hline \multicolumn{4}{|l|}{ Total Cr } \\
\hline$\left(\mathrm{mg} \mathrm{l}^{-1}\right)$ & 2.77 & 2.0 & 1.2 \\
\hline$\left(\mu \mathrm{moll} \mathrm{l}^{-1}\right)$ & 53.3 & 38 & 23 \\
\hline \multicolumn{4}{|l|}{$\mathrm{Cr}^{6+}$} \\
\hline$\left(\mathrm{mg} \mathrm{l}^{-1}\right)$ & & 0.1 & $<0.06$ \\
\hline$\left(\mu \mathrm{moll}^{-1}\right)$ & & 2 & $<1$ \\
\hline
\end{tabular}

TC: total carbon. TOC: total organic carbon. IC: inorganic carbon.

(III) [36]. Table 1 also shows that the amount of organic matter (quantified by the total organic carbon) and phosphates is negligible, whereas the concentrations of nitrates, fluoride and carbonates (expressed as IC) are of the same order of magnitude of nickel concentration.

\subsection{Optimization of the bioremediation process}

The efficiency of bioremediation process of metal ions, from effluents, is dependent both on the chemical speciation of the metal ions present in the effluent and the accumulation parameters of biomass used: $Q_{\max }$ and $\log K$; $Q_{\max }$ represents the maximum possible amount of metal ion adsorbed per unit weight of biomass and $\log K$ represents the equilibrium constant related to the affinity of the binding sites for the metals at a defined $\mathrm{pH}$ value. The most important factors which define metals speciation in the effluent are: $\mathrm{pH}$, redox potential, concentration of metal ions and complexing agents (organic and inorganic ones), as well as their affinity for metal ions. This last parameter is of paramount importance, as it will be discussed below.

The values of $Q_{\max }$, described in the literature, vary widely among the different types of biomass (bacteria, filamentous fungi, yeasts or algae) in evaluation and also within the same group of organisms [37]. This variability can be attributed to the different characteristics of the biomass, but also due to the different experimental conditions used, namely biomass concentration, $\mathrm{pH}$ of the solution and contact time between biomass and metals. As previously described, the heat-treated cells of S. cerevisiae used in the present work present intermediary values of metals accumulation $(\mathrm{Cu}, \mathrm{Ni}$ and $\mathrm{Zn})$, when compared with the values shown in others works, which have used S. cerevisiae cells [4].

For bioremediation treatment, $\mathrm{pH} 6.0$ was chosen as being a good commitment solution between the efficiency of biomass to biosorb metal ions and the amount of hydroxide necessary to raise the $\mathrm{pH}$ of the effluent. Extremes of $\mathrm{pH}$ often decrease the accumulation of heavy metals by the biomass. Yeast cells of $S$. cerevisiae are 
Table 2

Equilibrium affinity constants, as $\log K$, among the different ligands and copper, nickel and zinc, at $\mathrm{pH} 6.0$, and chromium at $\mathrm{pH} 5.0^{*}$.

\begin{tabular}{llllll}
\hline Ligand & \multicolumn{3}{l}{$\log K$} & & Reference \\
\cline { 2 - 4 } & $\mathrm{Cr}(\mathrm{OH})^{2+}$ & $\mathrm{Cu}^{2+}$ & $\mathrm{Ni}^{2+}$ & $\mathrm{Zn}^{2+}$ & \\
\hline Biomass & 3.56 & & & & {$[6]$} \\
& & 3.99 & 3.34 & 3.59 & {$[4]$} \\
$\mathrm{Cl}^{-}$ & $3.77^{\mathrm{a}}$ & $0.20^{\mathrm{b}}$ & $0.41^{\mathrm{b}}$ & $0.40^{\mathrm{b}}$ & \\
$\mathrm{F}^{-}$ & $8.86^{\mathrm{a}}$ & $1.80^{\mathrm{b}}$ & $1.40^{\mathrm{b}}$ & $1.30^{\mathrm{b}}$ & \\
$\mathrm{NO}_{3}{ }^{-}$ & $2.30^{\mathrm{a}}$ & $0.50^{\mathrm{b}}$ & $0.40^{\mathrm{b}}$ & $0.40^{\mathrm{b}}$ & \\
$\mathrm{HCO}_{3}{ }^{-}$ & - & $-3.56^{\mathrm{c}}$ & - & - & {$[32]$} \\
$\mathrm{SO}_{4}{ }^{2-}$ & $2.38^{\mathrm{d}}$ & $2.36^{\mathrm{b}}$ & $2.10^{\mathrm{b}}$ & $1.50^{\mathrm{b}}$ & \\
$\mathrm{H}_{2} \mathrm{PO}_{4}^{-}$ & $6.42^{\mathrm{a}}$ & - & - & $2.34^{\mathrm{b}}$ & \\
\hline
\end{tabular}

* Conditional affinity constants were calculated assuming the following equilibriums, wherein $\mathrm{M}$ is metal and $\mathrm{L}$ is ligand:

a $\mathrm{Cr}(\mathrm{OH})^{2+}+\mathrm{L}+\mathrm{H}^{+} \leftrightarrows \mathrm{CrL}+\mathrm{H}_{2} \mathrm{O}$.

b $\mathrm{M}+\mathrm{L} \leftrightarrows \mathrm{ML}$.

c $\mathrm{Cu}^{2+}+\mathrm{HCO}_{3}^{-} \leftrightarrows \mathrm{CuCO}_{3}+\mathrm{H}^{+}$

d $\mathrm{Cr}(\mathrm{OH})^{2+}+\mathrm{SO}_{4}^{2-} \leftrightarrows \mathrm{CrOHSO}_{4}$

able to remove heavy metals from wastewaters between $\mathrm{pH} 5.0$ and 9.0 [5], being $\mathrm{pH}$ close to 5-6 as the optimal for $\mathrm{Cu}^{2+}, \mathrm{Cd}^{2+}, \mathrm{Pb}^{2+}$, $\mathrm{Ni}^{2+}, \mathrm{Zn}^{2+}$ and $\mathrm{Cr}^{3+}$ biosorption by yeast cells $[5,6,8,10,38]$. At $\mathrm{pH}$ 6.0 , the main chemical groups of biomass surface, that are able to participate in the removal of metal cations (carboxyl, phosphate, sulfydryl, hydroxyl and nitrogen-containing groups), are already totally (carboxylic acids) or partially (phosphate and amine groups) deprotonated [32]. As a consequence, good $Q_{\max }$ are obtained. On the other hand, $\mathrm{pH} 6$ is the minimum $\mathrm{pH}$ value limit for discharging the wastewaters according to the Portuguese law (Table 1) and thus the $\mathrm{pH}$ of the effluents should be obligatorily raised up to 6 before being discharged. Additionally, if effluents also contain large amounts of other metal ions [e.g. copper and chromium (III) ions], they will start to precipitate at this $\mathrm{pH}$ value, as metal hydroxides [32], and thus more biomass will be available for removing nickel. However, the use of high $\mathrm{pH}$ values originates larger hydroxide consumptions and precipitation of other metals (e.g. nickel and zinc) hydroxides starts to occur [32].

The major driving force for the success of an efficient bioremediation treatment of an effluent containing metal ions is the relative affinity of each metal for biomass versus the several ligands (inorganic and organic ligands) present in the effluent, which can compete with yeast cells. Thus, in order to optimize the conditions of the bioremediation process, metal affinity constants among metal ions and inorganic ligands and yeast cells of $S$. cerevisiae were taking into account (Table 2). For all metals, unless chromium, affinity constants of the aquocomplex metal ion, $\mathrm{M}^{2+}$ (aq) were considered. In the case of chromium, this metal ion is very acidic and starts to hydrolysis at about $\mathrm{pH} 2$; in an aqueous solution, $\mathrm{Cr}(\mathrm{OH})^{2+}$ (aq) is the major species present in solution before precipitation of $\mathrm{Cr}(\mathrm{OH})_{3}$ occurs and this is the reason why we have included the affinity constants for this component in Table 2. A diagram exemplifying the competitive effect of ligands, present in the effluent, with yeast cells biomass is shown in Fig. 1 .

The analysis of Table 2 shows that, for copper, nickel and zinc, the affinity constants between metal ions and yeast biomass are much higher (two decades or more) than with some inorganic ligands. The relative magnitude of the affinity constants indicate that carbonates, chlorides, fluorides and nitrates do not compete with biomass for these metal ions even if present in large excess. In practice, $\mathrm{MHCO}_{3}, \mathrm{MCl}, \mathrm{MF}$ and $\mathrm{MNO}_{3}$ species, corresponding to reactions 2, 3, 4 and 5, respectively (Fig. 1 ), are not formed in appreciable extension; thus, accumulation of copper and/or nickel and/or zinc ions by yeast cells (reaction 1 ) in effluents containing carbonates and/or chlorides and/or fluorides and/or nitrates, would not be influenced by the presence of these ligands. Table 2 also shows

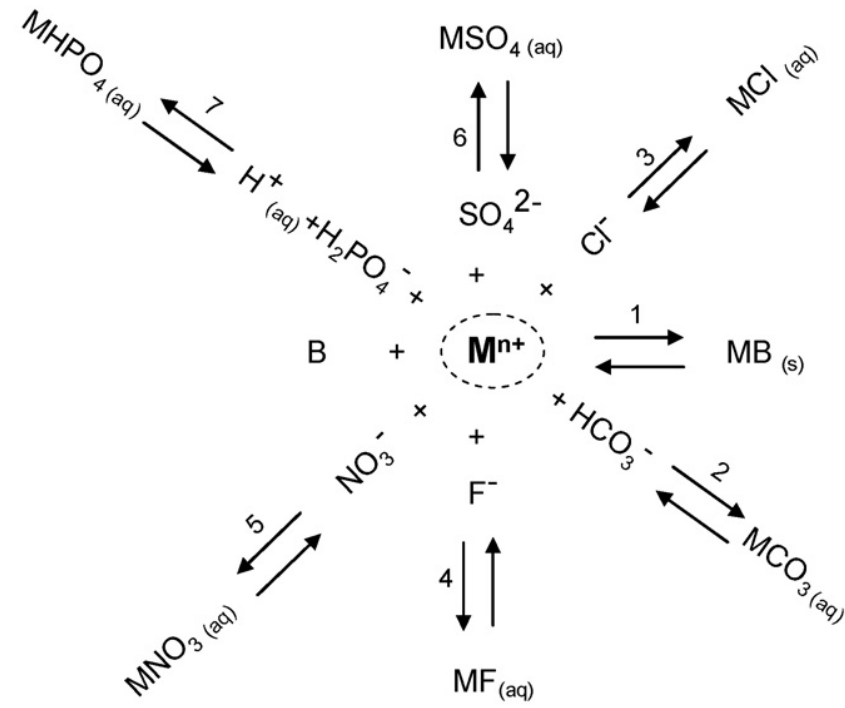

Fig. 1. Diagrammatic representation of metal-ligands interactions. Metal ions: $\mathbf{M}^{\mathrm{n}+}$ Biomass (yeast cells): B. For simplicity of representation, the charges of the complexes were omitted. Yeast cells are able to remove heavy metals from industrial effluents (reaction 1). The presence of ligands in the effluents (reactions 2-7) can reduce the efficiency of the process by competing with biomass for metal removal.

that the affinity constants between copper or zinc ions and yeast biomass are much higher (two decades or more) than with sulphates. On the other hand, the relative magnitude of the affinity constants between nickel ions and sulphates or biomass only differs one decade. These values anticipate that effluents containing molar concentrations of sulphates much higher than that of nickel ions can compete with yeast cells and thus will reduce the bioremediation efficiency (reaction 6). However, this effect can be more or less pronounced depending on the amount of biomass used. Theoretical simulations of the bioremediation process using $1.5 \mathrm{~g} \mathrm{l}^{-1}$ of biomass, of an effluent with the same composition of the effluent described in Table 1, and the same effluent but with a concentration of sulphates 10 times higher ( $3740 \mathrm{mg} \mathrm{l}^{-1}$ ), predict a reduction of $24 \%$ of the bioremediation efficiency, i.e., the \% of nickel associated with the biomass (Fig. 2); for the lower concentration of sulphates ( $374 \mathrm{mg} \mathrm{l}^{-1}$ ), the fraction of nickel associated with biomass is $35 \%$, reducing to $11 \%$ in the presence of a concentration of sulphates ten times higher (Fig. 2). High concentrations of sulphates can occur in these type of effluents when reduction of chromium (VI) to chromium (III) is performed with a sulphuric acid solution of bissulphite. Taking into account the negative impact of sulphates in the bioremediation of nickel (Fig. 2), the use of sulphuric acid should be substituted by another mineral acid, for example nitric or chloridric acid, when acidification is necessary for previous reduction of chromium (VI) to chromium (III). Besides, addition of bissulphite in the treatment tank can be reduced by controlling the redox potential and the $\mathrm{pH}$; usually a redox potential of $270 \mathrm{mV}$ and a $\mathrm{pH}$ of 2.5 are enough to reduce efficiently chromium (VI) to chromium (III) [35].

The analysis of the relative magnitude of the affinity constants among chromium (III) and biomass or the various inorganic ligands (Table 2), anticipate that, effluents containing fluorides or phosphates complex chromium (reactions 4 and 7 , respectively), and thus, the biosorption process under these conditions can be reduced (Fig. 1).

Copper, chromium, nickel and zinc are the metal ions most widely found in the electroplating effluents and the affinity between biomass used in this work and these metal ions follows the following order: $\mathrm{Cu} \gg \mathrm{Cr} \cong \mathrm{Zn}>\mathrm{Ni}$ (values of $\log \mathrm{K}$ are presented in Table 2) $[4,6]$. The treatment of effluents containing multi-elements 


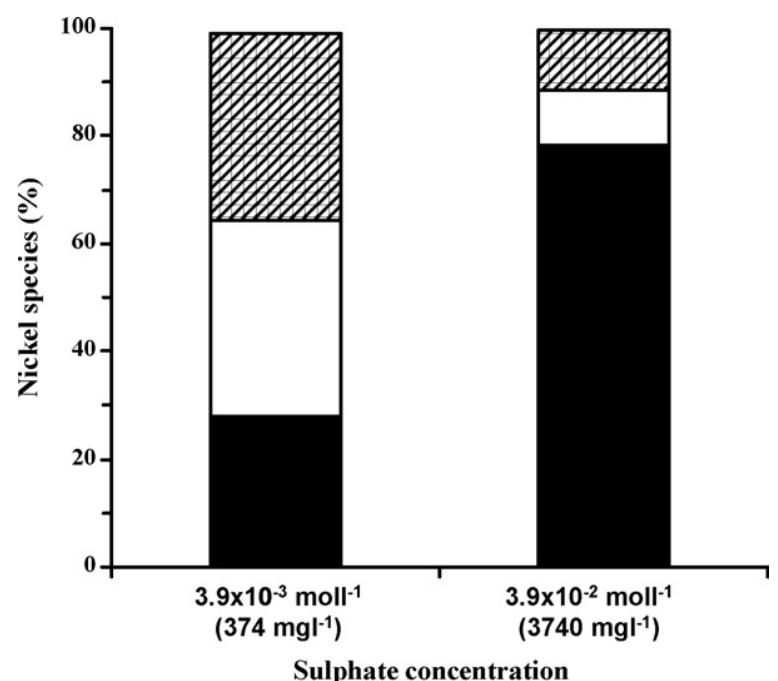

Fig. 2. Simulation of the influence of sulphate concentration on the nickel speciation in the presence of $1.5 \mathrm{~g} \mathrm{l}^{-1}$ of inactivated biomass of $S$. cerevisiae NCYC 1364. Free nickel ions (white part of the bar); nickel associated with biomass (dashed part of the bar); nickel associated with sulphate (black part of the bar). The different species of nickel were calculated using the chemical equilibrium computer program (MINEQL+); for more details about calculations see Section 2.6.

is more complex because metal ions compete for binding sites; as a consequence, displacement of one metal species by another, which has higher affinity for biomass binding sites, can occur [39]. Thus, for an efficient bioremediation process, the amount of biomass ([Biomass]) when compared with the total amount of metals $\left(\sum[M]\right)$ should be in excess in order to have sufficient available biomass sites for all metals accumulation, including those with lower affinity for biomass. However, as lower as the affinity constants between biomass and metal ions are, less amount of metal ions will be biosorbed when equilibrium is attained. Since biomass presents much lower affinity to nickel than copper (five times less) and chromium or zinc (two times less) (Table 2), this means that the efficiency of bioremediation of effluents containing nickel, among the other three metal ions (chromium, copper and zinc), will be conditioned by nickel affinity.

If we want to remove efficiently metals from real multi-metal systems, which contain nickel among other metal ions, nickel biosorption is one of the real challenges that should be firstly studied. Due to this, we decided to study in detail the biosorption of real electroplating effluent containing this metal.

In order to optimize the amount of yeast cells required to treat the effluent described in Table 1, in a batch mode, with no more than three batches, theoretical calculations were done using MINEQL+ software [31]. Thus, for predicting the metal accumulated by the yeast cells, an iterative process of chemical simulations was performed; for this purpose, the program was run with a fixed concentration of biomass in the range between 1.5 and $12 \mathrm{gl}^{-1}$, at $\mathrm{pH}$ 6.0 , assuming the chemical composition of the effluent (Table 1 ). The analysis of Fig. 3A predicts that the application of $1.5 \mathrm{~g} \mathrm{l}^{-1}$ of biomass will remove about a third of nickel concentration in the first batch. After the fifth batch, the amount of nickel (free nickel ion plus $\mathrm{NiSO}_{4}$ ) present in the effluent will be below the limit of discharge criteria according to the Portuguese law. On the other hand, chemical simulations performed with $12 \mathrm{~g} \mathrm{l}^{-1}$ of yeast cells, in each batch, predicted the removal of about $84 \%$ of nickel in the first batch; according to these calculations, after the second batch, the concentration of nickel (free nickel ion plus $\mathrm{NiSO}_{4}$ ) in the effluent will be below the limit of discharge criteria (Fig. 3B). Amounts of 1.5 and $12 \mathrm{~g} \mathrm{l}^{-1}$ of biomass correspond to molar concentrations of $5.4 \times 10^{-4}$ and $4.5 \times 10^{-3} \mathrm{moll}^{-1}$ [4], respectively. For these exper-
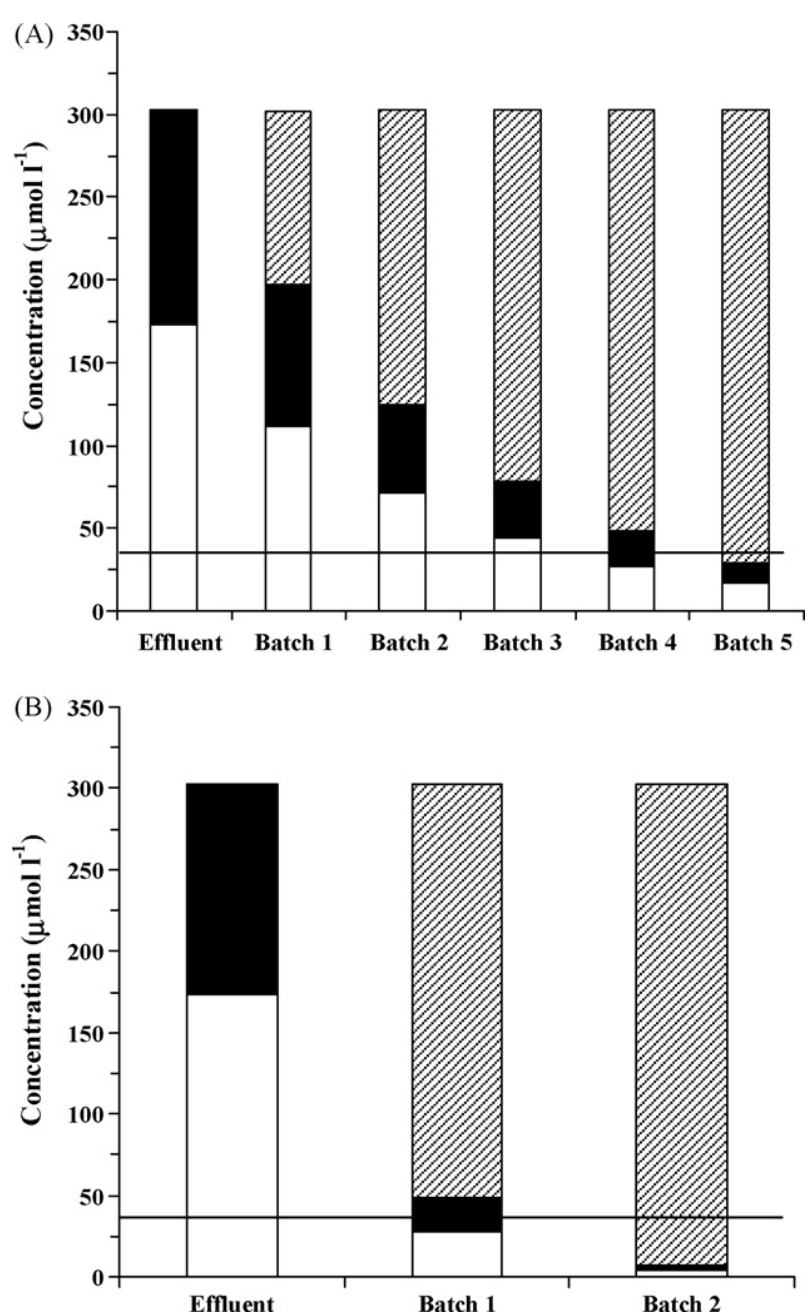

Fig. 3. Simulation of the influence of yeast biomass concentration in the nickel

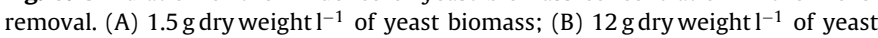
biomass. Nickel ions (white part of the bar); nickel associated with inactivated yeast of S. cerevisiae NCYC 1364 (dashed part of the bar); nickel associated with sulphate (black part of the bar). Calculations of the nickel concentration species was done as described in Fig. 2. Solid line represents the Portuguese wastewater limit discharge criteria for nickel: $2.0 \mathrm{mg} \mathrm{l}^{-1}\left(34 \mu \mathrm{moll}^{-1}\right)$.

imental conditions, the molar ratios between the concentration of biomass and nickel are 1.8 and 14.9, respectively. These results evidence that a large excess of biomass in relation to the total molar amount of metals present in the effluents should be used to overcome the lower affinity of biomass to nickel and sulphates competition.

\subsection{Bioremediation of real and synthetic effluents using a batch reaction system}

In this work, inactivated (at $45^{\circ} \mathrm{C}$ ) yeast cells of a brewing strain of $S$. cerevisiae were used in the treatment of a real electroplating effluent containing nickel above the legal limit of discharge criteria; in order to compare the impact of inorganic ligands, present in the raw effluent, on the bioremediation process, two synthetic effluents (named, synthetic effluent 1 and synthetic effluent 2) with the same amount of metals as the industrial effluent were prepared. In the case of synthetic effluent 1 , the same amount of inorganic ligands $\left(\mathrm{Cl}^{-}, \mathrm{NO}_{3}{ }^{-}\right.$and $\left.\mathrm{SO}_{4}{ }^{2-}\right)$ of the industrial effluent was also added.

Taking into account the information given above, $12 \mathrm{gl}^{-1}$ of yeast cells were used to remove nickel from the effluents, in a batch mode. A series of batches, using new biomass in each 
Table 3

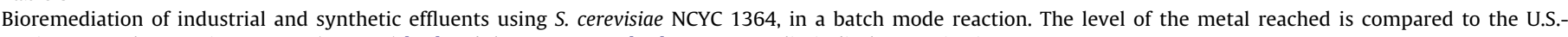
Environmental Protection Agency (US-EPA) [34] and the Portuguese [33] wastewater limit discharge criteria.

\begin{tabular}{|c|c|c|c|c|c|c|c|}
\hline & \multicolumn{7}{|c|}{ Metal concentration $\left(\mathrm{mg} \mathrm{l}^{-1}\right)^{\#}$} \\
\hline & \multirow[t]{2}{*}{ Effluent } & \multicolumn{2}{|c|}{ Limit discharge criteria } & \multirow[t]{2}{*}{ Original effluent } & \multirow[t]{2}{*}{ After 1st batch } & \multirow[t]{2}{*}{ After 2nd batch } & \multirow[t]{2}{*}{ After 3rd batch } \\
\hline & & US-EPA & Portuguese law & & & & \\
\hline \multirow[t]{3}{*}{ Nickel } & Industrial & 3.98 & 2.0 & $17.8 \pm 0.1$ & $5.4 \pm 0.5$ & $2.7 \pm 0.7$ & $2 \pm 1$ \\
\hline & Synthetic 1 & & & $19 \pm 1$ & $6.7 \pm 0.3$ & $3.2 \pm 0.4$ & $2.2 \pm 0.3$ \\
\hline & Synthetic 2 & & & $19 \pm 1$ & $5.3 \pm 0.4$ & $2.6 \pm 0.4$ & $1.6 \pm 0.3$ \\
\hline
\end{tabular}

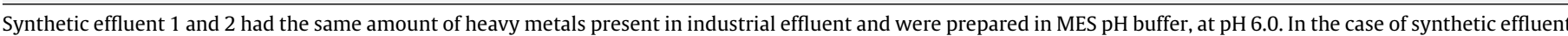
1 , the same amount of inorganic ligands $\left(\mathrm{Cl}^{-}, \mathrm{NO}_{3}{ }^{-}\right.$and $\left.\mathrm{SO}_{4}{ }^{2-}\right)$ of the industrial effluent was also added.

\# Mean and standard deviation of three independent experiments performed in duplicate $(n=6)$.

batch, was implemented in the effluents (real and synthetics). Final concentrations of nickel and cumulative percentages of nickel removal obtained, after each batch in all effluents, are present in Table 3 and Fig. 4, respectively. Theoretical simulation of cumulative percentages of nickel removal were also calculated and included in Fig. 4; for this purpose, chemical speciation of nickel at $\mathrm{pH} 6.0$ was calculated, assuming the total concentration of nickel, biomass and inorganic ligands present in the effluent, as well as the affinity constants between nickel and the ligands (biomass and inorganic ligands) using the MINEQL+ software [31].

After the first batch, the percentages of nickel removal were $70 \%$, $65 \%$ and $72 \%$ (Fig. 4), for real and synthetic effluents with and without ligands, respectively. In the second batch, the replacement of biomass lowered the amount of nickel in solution to 2.7, 3.2 and $2.6 \mathrm{mgl}^{-1}$ in real and synthetic effluents, respectively (Table 3 ). After the third batch, the concentration of nickel lowered to 2, 2.2 and $1.6 \mathrm{mg} \mathrm{l}^{-1}$ in real and synthetic effluents (Table 3), which corresponded to $89 \%, 88 \%$ and $92 \%$ of total cumulative removals, respectively (Fig. 4). This means that, after the implementation of the bioremediation process described in the present work, the concentration of nickel in the effluents reached the quality criteria for industrial effluents discharge (3.98 and $2.0 \mathrm{mg} \mathrm{l}^{-1}$ ), after the second

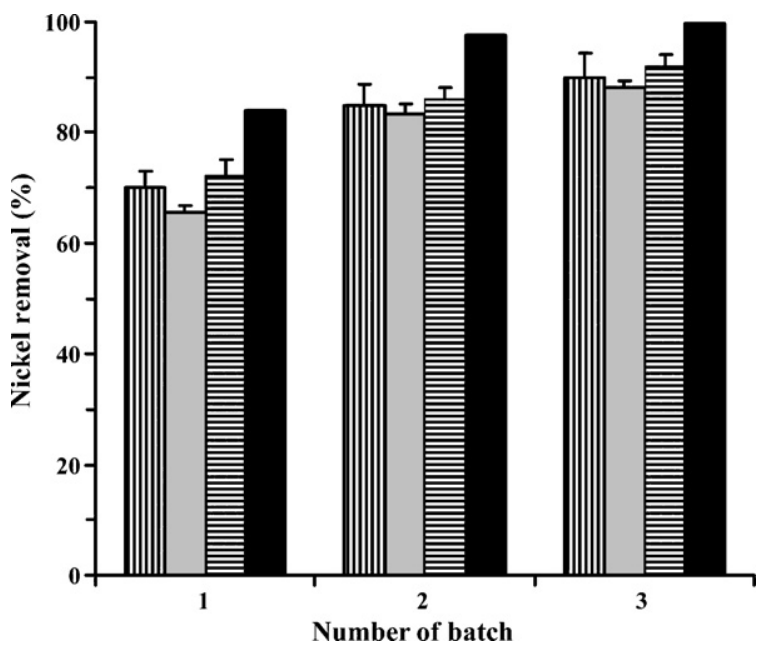

Fig. 4. Comparison of the theoretical and real nickel removal by S. cerevisiae NCYC 1364 through a series of sequential batches in bench scale experiments. Bar with vertical lines: industrial effluent; grey bar: synthetic effluent 1 (with the same amount of inorganic ligands of industrial effluent); bar with horizontal lines: synthetic effluent 2 (without addition of inorganic ligands); black bar: theoretical value. Theoretical calculations were performed as described in Fig. 2. Experimental assays were carried out with $12 \mathrm{~g}$ dry weight $\mathrm{l}^{-1}$ of biomass added to the effluents reported in Table 3. The effluents plus the biomass were placed in plastic flasks and shaken at $150 \mathrm{rpm}$, at $25^{\circ} \mathrm{C}$. After $30 \mathrm{~min}$ of contact of the biomass with the effluents, cells were removed and the supernatant added to a fresh yeast biomass, in a subsequent batch. Values are the mean and standard deviation of two replicates of three independent experiments $(n=6)$. or third batch according to U.S.-Environmental Protection Agency [34] and Portuguese law [33] respectively.

The comparative analysis of these results shows that equivalent nickel removal values were obtained from all effluents. Together, these results are in agreement with our prevision that the amount of inorganic ligands, as well as the small amount of organic matter, present in the real effluent did not influence the nickel removal.

Experimental values of nickel removal from effluents were lower than the theoretical simulated values (Fig. 4). The overestimation of the amount of nickel accumulated by the biomass can be a consequence of the stability constants between nickel and inorganic ligands used in the theoretical simulation calculations were not determined in the experimental conditions of the effluents (ionic strength and temperature) and/or due to the release of some ligands by the biomass, which will complex nickel and thus reduce the efficiency of bioremediation process $[18,19]$.

These results evidence that the use of a large excess of yeast biomass comparatively to nickel allowed an efficient removal of nickel from real and synthetic effluents, reducing the amount of metal in solution to the limit of discharge of wastewater in natural waters.

\section{Conclusions}

This work examines the influence of the competitive effect of inorganic ligands (carbonates, chlorides, fluorides, phosphates, nitrates and sulphates), which can be present in real electroplating effluents, on the biosorption of chromium, copper, nickel and zinc ions by yeast cells of $S$. cerevisiae. The presence of high concentrations of carbonates, chlorides, fluorides, and nitrates do not compete with biomass for copper, nickel and zinc ions. On the other hand, the presence of phosphates or fluorides can reduce the efficiency of chromium biosorption. The presence of sulphates, at molar concentrations higher than that of biomass, can compete with biomass for nickel. To avoid high concentrations of sulphates in the electroplating effluents, and thus the problem of sulphates competition, we suggest the substitution of sulphuric by nitric acid (or chloridric acid) in the bissulphite solution for reduction of chromium (VI) to chromium (III) in the wastewater treatment plants of the electroplating industries.

Theoretical simulations, validated experimentally, have shown that for the bioremediation treatment of effluents containing nickel at $\mathrm{pH}$ 6.0, using a serial batch reactor, the amount of biomass ([Biomass]), when compared with the total amount of metals ( $\sum$ [M]) should be in excess. We have demonstrated that the molar ratio of [Biomass]/( $\left.\sum[\mathrm{M}]\right)$ to be implemented can be computationally predicted, with an acceptable precision, if the concentrations of nickel and sulphates present in the effluent, as well as the affinity parameters $\left(Q_{\max }\right.$ and $\left.\log K\right)$ of the biosorbent, are known.

Finally, brewing flocculent cells of $S$. cerevisiae seems to be a promissory biomass alternative for the removal of nickel from industrial electroplating effluents. After the third batch, the amount 
of nickel in the effluent was reduced to values below the limit of discharge of wastewater in natural waters. This corresponded to a removal of nickel of $89 \%$.

\section{Acknowledgments}

The authors thank to the "Fundação para a Ciência e a Tecnologia" (FCT) from Portuguese Government for the financial support of this work with FEDER founds, by the Project POCTI/CTA/47875/2002. Manuela D. Machado is also gratefully acknowledged for a grant scholarship financed under the same project and another grant from FCT (SFRH/BD/31755/2006).

\section{References}

[1] B. Volesky, Detoxification of metal-bearing effluents: biosorption for the next century, Hydrometallurgy 59 (2001) 203-216.

[2] E.V. Soares, G. De Coninck, F. Duarte, H.M.V.M. Soares, Use of Saccharomyces cerevisiae for $\mathrm{Cu}^{2+}$ removal from solution: the advantages of using a flocculent strain, Biotechnol. Lett. 24 (2002) 663-666.

[3] M.D. Machado, M.S.F. Santos, C. Gouveia, H.M.M. Soares, E.V. Soares, Removal of heavy metals using a brewer's yeast strain of Saccharomyces cerevisiae: the flocculation as a separation process, Bioresour. Technol. 99 (2008) 2107-2115.

[4] M.D. Machado, S. Janssens, H. Soares, E.V.Soares, Removal of heavy metals using a brewer's yeast strain of Saccharomyces cerevisiae: advantages of using dead biomass, J. Appl. Microbiol. 106 (2009) 1792-1804.

[5] D. Brady, J.R. Duncan, Bioaccumulation of metal cations by Saccharomyces cerevisiae, Appl. Microbiol. Biotechnol. 41 (1994) 149-154.

[6] A.I. Ferraz, J.A. Teixeira, The use of flocculating brewerǐs yeast for $\mathrm{Cr}(\mathrm{III})$ and $\mathrm{Pb}$ (II) removal from residual wastewaters, Bioprocess. Eng. 21 (1999) 431-437.

[7] A.I. Zouboulis, K.A. Matis, N.K. Lazaridis, Removal of metal ions from simulated wastewater by Saccharomyces yeast biomass: combining biosorption and flotation processes, Sep. Sci. Technol. 36 (2001) 349-365.

[8] A. Özer, D. Özer, Comparative study of the biosorption of $\mathrm{Pb}(\mathrm{II}), \mathrm{Ni}(\mathrm{II})$, and $\mathrm{Cr}(\mathrm{VI})$ ions onto $S$. cerevisiae: determination of biosorption heats, J. Hazard. Mater. B 100 (2003) 219-229.

[9] P. Vasudevan, V. Padmavathy, S.C. Dhingra, Kinetics of biosorption of cadmium on Baker's yeast, Bioresour. Technol. 89 (2003) 281-287.

[10] M. Mapolelo, N. Torto, Trace enrichment of metal ions in aquatic environments by Saccharomyces cerevisiae, Talanta 64 (2004) 39-47.

[11] K. Parvathi, R. Nagendran, Biosorption of chromium from effluent generated in chrome-electroplating unit using Saccharomyces cerevisiae, Sep. Sci. Technol. 42 (2007) 625-638.

[12] T.M. Florence, Trace-element speciation and aquatic toxicology, Trac-Trends Anal. Chem. 2 (1983) 162-166.

[13] P.X. Sheng, Y.P. Ting, J.P. Chen, L. Hong, Sorption of lead, copper, cadmium, zinc, and nickel by marine algal biomass: characterization of biosorptive capacity and investigation of mechanisms, J. Colloid Interface Sci. 275 (2004) 131-141.

[14] M.N. Hughes, R.K. Poole, Metal speciation and microbial-growth - the hard (and soft) facts, J. Gen. Microbiol. 137 (1991) 725-734.

[15] S.V. Avery, J.M. Tobin, Mechanism of adsorption of hard and soft metal ions to Saccharomyces cerevisiae and influence of hard and soft anions, Appl. Environ. Microbiol. 59 (1993) 2851-2856.

[16] G.M. Gadd, Interaction of fungi with toxic metals, New Phytol. 124 (1993) 25-60.

[17] P. Simmons, J.M. Tobin, I. Singleton, Considerations on the use of commercially available yeast biomass for the treatment of metal-containing effluents, J. Ind. Microbiol. 14 (1995) 240-246.
[18] E.V. Soares, A.P.S.R. Duarte, R.A. Boaventura, H.M.V.M. Soares, Viability and release of complexing compounds during accumulation of heavy metals by a brewer's yeast, Appl. Microbiol. Biotechnol. 58 (2002) 836841.

[19] E.V. Soares, K. Hebbelinck, H.M.V.M. Soares, Toxic effects caused by heavy metals in the yeast Saccharomyces cerevisiae: a comparative study, Can. J. Microbiol. 49 (2003) 336-343.

[20] P.R. Norris, D.P. Kelly, Accumulation of cadmium and cobalt by Saccharomyces cerevisiae, J. Gen. Microbiol. 99 (1977) 317-324.

[21] Y.S. Yun, D. Park, J.M. Park, B. Volesky, Biosorption of trivalent chromium on the brown seaweed biomass, Environ. Sci. Technol. 35 (2001) 4353-4358.

[22] J. Wang, C. Chen, Biosorption of heavy metals by Saccharomyces cerevisiae: a review, Biotechnol. Adv. 24 (2006) 427-451.

[23] G.M. Gadd, Biosorption: critical review of scientific rationale, environmental importance and significance for pollution treatment, J. Chem. Technol. Biotechnol. 84 (2009) 13-28.

[24] E. Romera, F. Gonzalez, A. Ballester, M.L. Blazquez, J.A. Munoz, Biosorption of heavy metals by Fucus spiralis, Bioresour. Technol. 99 (2008) 46844693.

[25] R. Herrero, P. Lodeiro, C. Rey-Castro, T. Vilarino, M.E.S. de Vicente, Removal of inorganic mercury from aqueous solutions by biomass of the marine macroalga Cystoseira baccata, Water Res. 39 (2005) 3199-3210.

[26] I. de Vargas, L.E. Macaskie, E. Guibal, Biosorption of palladium and platinum by sulfate-reducing bacteria, J. Chem. Technol. Biotechnol. 79 (2004) 4956.

[27] T. Pumpel, L.E. Macaskie, J.A. Finlay, L. Diels, M. Tsezos, Nickel removal from nickel plating waste water using a biologically active moving-bed sand filter, Biometals 16 (2003) 567-581.

[28] APHA, AWWA, WPCF, Standard Methods for the Examination of Water and Wastewater, 20th ed., American Public Health Association, Washington, D.C., 1998.

[29] H.M.V.M. Soares, P.C.F.L. Conde, A.A.N. Almeida, M.T.S.D. Vasconcelos, Evaluation of $\mathrm{N}$-substituted aminosulfonic acid $\mathrm{pH}$ buffers with a morpholinic ring for cadmium and lead speciation studies by electroanalytical techniques, Anal. Chim. Acta 394 (1999) 325-335.

[30] H.M.V.M. Soares, S.C. Pinho, M.G.R.T.M. Barros, Influence of N-substituted aminosulfonic acids with a morpholinic ring $\mathrm{pH}$ buffers on the redox processes of copper or zinc ions: a contribution to speciation studies, Electroanalysis 11 (1999) 1312-1317.

[31] W.D. Schecher, D.C. McAvoy, MINEQL+: a Chemical Equilibrium Modeling System, Version 4.5 for Windows, User's Manual, Environmental Research Software Hallowell, Maine., 2003.

[32] A.E. Martell, R.M. Smith, NIST Standard Reference Database 46 Version 8.0, NIST Critically Selected Stability Constants of Metal Complexes Database, US Department of Commerce, National Institute of Standards and Technology, 2004.

[33] Decreto-lei, 236/98, 1 Agosto de 1998. Anexo XVIII. Valores limite de emissão na descarga de águas residuais. Diário da República, série I-A, 176/98, 3676.

[34] US-EPA, Guidance manual for electroplating and metal finishing pretreatment standards, EPA-440/1-84/091g, US Environmental Protection Agency, Washington, DC, 1984.

[35] M. Pourbaix, Atlas of Electrochemical Equilibria in Aqueous Solutions, Houston, Texas, USA, 1974

[36] J. Wang, Y. Li, Chemical reduction/oxidation, in: L.K. Wang, N.C. Pereira, Y. Hung (Eds.), Advanced Physicochemical Treatment Processes, Handbook of Environmental Engineering, vol.4, Humana Press, 2006, p. 485, cap 15.

[37] J.L. Wang, C. Chen, Biosorbents for heavy metals removal and their future, Biotechnol. Adv. 27 (2009) 195-226.

[38] K. Junghans, G. Straube, Biosorption of copper by yeasts, Biol. Met. 4 (1991) 233-237.

[39] D. Brady, A. Stoll, J.R. Duncan, Biosorption of heavy metal cations by non-viable yeast biomass, Environ. Technol. 15 (1994) 429-438. 